\title{
Individual development in a neoliberal context: Climbing to a 'glass ceiling'? A plea for liberal pedagogy in upper secondary vocational education
}

\author{
Maarten Matheus van Houten
}

University of Glasgow, United Kingdom (m.van-houten.1@research.gla.ac.uk)

\begin{abstract}
This essay addresses the issue that a neoliberal focus might have an adverse effect on a secondary vocational education student's personal development and opportunities in higher education. Originating from neoliberal conditions, in upper secondary vocational education there is a strong focus on marketable skills with limited space for acquiring critical thinking and analytical skills, resulting in impediments concerning admittance to higher education as well as low success rates of those admitted. Also, talent development and differentiation are contested under these neoliberal conditions. It is argued that liberal pedagogy is necessary as a means to scaffold especially critical thinking skills and to foster talent development in upper secondary vocational education to cope with this issue and to create more equal opportunities for vocational students from various levels. In the concluding thoughts those involved are encouraged to reconsider preparation for post-secondary education related to admittance and study success.
\end{abstract}

Keywords: higher education, vocational education and training, pedagogy, globalisation and internationalisation, neoliberalism 


\section{Introduction}

In vocational education in general, and certainly in upper secondary vocational education, there is a strong focus on marketable skills. Also, from the international perspective, programmes that are developed together with the market and pre-set curricula are common practice.

However, this neoliberal focus might have an adverse effect on a student's personal development and opportunities in post-secondary education. In this paper I argue that liberal pedagogy is beneficial if not necessary in upper secondary vocational education to cope with this issue. As an example, I will draw on the education system of The Netherlands, as over the past two decades this system has been increasingly formed by both traditional and neoliberal influences. This approach requires a critical stance towards the educational sectors involved, aimed at reconsideration of curricula and collaborative learning-teaching trajectories, but does not mean that, given the globalisation and tendencies in play, neoliberal influences and markets demand should be ignored.

Classical liberal theory emphasizes the importance of education for the construction of the self. Wringe (1997, p. 115) holds that individuals should not 'use their life to serve the goals, interests and aspirations of another, unless they so choose.' The capacity to critically question and analyse conditions and concepts present in our lives, as well as acquiring knowledge through enquiry, are essential within this type of pedagogy that aims at self-actualisation and free, autonomous individuals. In this paper, I adopt a 'contemporary' interpretation of liberal education, in which education is not primarily for the upper-class white male as was historically the case, but offers ownership of thought and speech for each individual irrespective of class, gender or ethnicity (see Nussbaum, 1997).

Contrasting this liberal view, neoliberals argue that education is about investing in the future of the market through the individual. Giroux (2002) states that under neoliberal conditions, the individual is defined through market-driven notions, in which competition and consumption are important drivers. Neoliberal education produces self-interested, entrepreneurial graduates through standardised, fixed curricula, making them globally competitive and prepared for the market. The Dutch government, for example, describes the neoliberal condition rather explicitly stating it is the government's responsibility to equip the education sector in such a way that students are able to develop and flourish in the European knowledge society and that institutions are able to acquire a firm position within the international education market (Ministerie van Onderwijs, Cultuur \& Wetenschap [OCW], 2000, p. 2). This statement reflects the neoliberal governmental rationality and what Fougner (2006) would call governance aimed at actively establishing certain legal and institutional conditions.

Neoliberal conditions in education do not necessarily preclude autonomous selves or opportunities for personal development and critical thinking. But there 
are significant differences between neoliberal and liberal education concerning the position of the individual and even more the outcomes and purposes of learning. Interestingly, liberal pedagogy builds on critical thinking and analysis, and according to Sneyers and De Witte (2016), in neoliberal higher education too, essential to learning and success is a student's intellectual capacity, that is, the capacity to process information, to think, analyse and judge - skills that require reasoning and enquiry. It is exactly on this point that the neoliberal condition is worrying. Focussing heavily on vocational skills and fixed requirements within upper secondary vocational education may not only curb personal development, but, due to a lack of analytical skills and reasoning capability, also makes it arduous to continue to post-secondary education, that is, higher education (hereafter also: HE). Additionally, the Dutch government aims to generate differentiation and talent development within the HE sector in order to create a more diverse national alumni corps (OCW, 2015). The central issue of this article addresses the issue that liberal pedagogy, being concerned with certain skills, has an important role to play in this context of the education system.

This paper adopts a futures studies approach and proceeds in three sections. In the first section, I will provide a description of the area of concern, elaborating on the problem just introduced concisely. In the second and third sections, analyses of a probable future and respectively preferable future will be put forward. Regarding the exemplary Dutch education system, the timeframe concerned is a middle range future (as indicated by Earl Joseph), until approximately 2025. This is because the qualifications in upper secondary education have been revised in 2016 and these examination criteria will be used for approximately eight years. Another reason stems from the Dutch government's higher education agenda and the upper secondary vocational education council's agenda, both running from 2015 to 2025.

\section{Context and issues}

This section provides the context of the issue raised in the introduction. At the core of this is the argument that students wanting to proceed from upper secondary vocational education to HE seem to fall short when it concerns skills like critical thinking and conducting an analysis based on rational thinking (see Lowe \& Cook, 2003; Van Asselt, 2014). This often leads to either no admittance to HE or exiting HE early, with the possible drawback of not living up fully to one's potential. In the following paragraphs, contextualising the issue, I will first sketch the situation in Dutch education to provide a base for examples, after which I will argue what the issues are about, exploring the problem more specifically.

The Dutch education system is based on the 1968 'Mammoth Law'. It is a binary system distinguishing vocational and academic education (see Van Houten, 2018), consisting of compulsory primary education and secondary education 
with national examination, is aimed at attaining a certain level of knowledge and skills. After initial secondary school, students proceed to job-preparatory or academic education. There is upper secondary vocational education called Middelbaar BeroepsOnderwijs ('intermediate vocational education', also abbreviated as $\mathrm{MBO}$ henceforth) offering education up to EQF level four, and there are two kinds of higher education. The first type of HE is tertiary vocational education called Hoger BeroepsOnderwijs ('higher vocational education', also HBO henceforth) offering programmes on EQF levels five to seven, and the other type of HE is academic education (EQF levels six to eight). Here, I focus on upper secondary education and tertiary (or higher) vocational education. One reason for this is the fact that institutions offering these types of education explicitly deliver vocational graduates, allowing for neoliberal drivers to explicitly exhibit themselves in the education offered. Recognizing the prevalence of neoliberalism within vocational education, I find this situation worrying if this puts pressure on liberal pedagogy skills and values or on students' opportunities. Another reason for this focus derives from the possibilities the Dutch education system offers by law, but which in reality result in impediments.

Within MBO, about half a million students study vocational programmes for specific occupations (MBO-Raad, 2019). Examination criteria and learning outcomes are identical and diplomas are valid due to nationally recognised examination, although courses within programmes may differ between institutions. Because this type of education targets the production of skilled employees, programmes deal with vocational skills and content related to the occupational context. When analysis or reflection is required, often models or prescribed models (like SWOT analysis) are used, allowing little space for original, critical consideration. The vocational emphasis is also expressed in the overall architecture of curricula: courses and internships alternate during the week. The considerable amount of time dedicated to practice influences the time available for teaching. In my view, this results in an even greater emphasis on practice-related theory and knowledge, at the expense of developing thinking or (meta)cognitive capacities. After completing upper secondary education, MBO students are entitled to admittance to tertiary vocational education, with only few exceptions because of severe discrepancies between programmes. A nurse, for example, cannot be admitted to a bachelor's programme in accounting. Based on research and on the content of programmes and qualifications, the Minister of Education, Culture and Science (Bussemaker, 2013) selected seven such combinations for which admittance was precluded, making up for approximately $5 \%$ of all continuing students. However, HBO institutions are cautious when it comes to admitting upper secondary education graduates. Over the previous years, admittance to numerus fixus programmes increasingly is based on decentralized selection, that is, based on previous education results and motivation with the expectation that this would increase study success in HE (Inspectie van het Onderwijs, 2015). This 
might oppose the aim of keeping HE programmes open for admittance to a broad population. The existence of multiple routes and options to HE as provided by law leads to a trilemma: HBO institutions strive to higher study success rates, accessibility and high standards all at once (Sociaal en Cultureel Planbureau, 2004).

I would like to reconsider now why there is a precarious situation. From a liberal perspective, I would argue that the focus on content knowledge and vocational skills occupies student's development so that critical thinking and nonmarket-oriented personal development become subordinated within curricula. But even if liberal education would have to surrender to neoliberal conditions with a strong focus on vocational, marketable skills, would there be any complications at all if we do not bother with liberal pedagogy and the teaching of rational thinking or reflective and analytical skills? My answer would still be yes, based on a threefold argument.

First, studying in HE requires cognitive skills such as rational thinking, applying logics, and the capacity to scrutinise and analyse. Cognitive skills are foundational skills related to the learning process in HE, with research showing that cognitive skills contribute to achievement within HE (Naglieri, 2005; Naglieri \& Das, 2005). Sneyers and De Witte (2016) indicate that intellectual capacities, not content knowledge or experience, might very well be the most important determinant of success in HE. This also relates to the occupations for which students are trained. HE graduates are likely to have more responsibilities in their jobs and to have to deal with more problems than lower skilled employees. Problem solving requires, among other skills, questioning one's own reasoning, that is, it requires critical thinking and reflection (Billing, 2007). It seems that cognitive skills and critical thinking are required for success in $\mathrm{HE}$, but at the same time, students proceeding from secondary education to HE (tertiary education) are often insufficiently prepared (Lowe \& Cook, 2003; Van Asselt, 2014). Van Asselt (2014) states that one reason for this is the difference between mostly inductive education in secondary education and mostly deductive reasoning in HE. Using the Dutch example, this appears to be supported by the statistics. Approximately $40 \%$ of the MBO graduates continues in HBO (Van Weert et al., 2017), but just under $60 \%$ of these actually graduate (Onderwijsincijfers, n.d.a.), with one out of five students leaving in the first year (OCW, 2015). Additionally, in previous years, higher education institutions (also HEIs hereafter) have been sharpening entry requirements and over the past 10 years, as well the percentage of $\mathrm{MBO}$ graduates continuing in HBO has been declining (Herweijer \& Turkenburg, 2016; Onderwijsincijfers, n.d.b.). Herweijer and Turkenburg (2016) also show that HEIs struggle with entry requirements and selection procedures and the arithmetic and language entry levels of MBO graduates, for example in the field of teacher education. Although there might not be a causal relationship between these 
developments, at least they suggest a discrepancy between acquired levels before $\mathrm{HE}$ and entry expectations or requirements for HE.

The differences between secondary education and HE bring me to my second argument. Acknowledging the neoliberal condition in the education sector in general, admitting upper secondary education graduates to HE may be like a poor investment. Bringing back to memory the principle of producing globally competitive labourers, I assume 'competitive' also portends 'highly educated'. HEIs, aware of the risks given the graduation statistics of former upper secondary education students, are hesitant to admit these students, considering the investment involved in terms of money and staff. Using intake procedures including interviews, or complimentary tests in the application procedure, for instance, they may discourage or prohibit future students from applying to their institution. Also, if admitted, exams and teaching can be constructed in such way that some former upper secondary students are simply underprepared or unable to succeed. If the education system fails to create accomplishable opportunities to proceed and succeed on the educational ladder, graduates might be less competitive, and efforts might be in vain.

Thirdly, doing better and being competitive means being different when needed (Magretta, 2002). Related to the issue of competitiveness is the changing labour market. Monotonous work and stability are losing value, whereas flexibility, knowledge and creativity gain importance in the work sphere, with the number of routinely jobs decreasing (CEDEFOP, 2011; Goos et al., 2010; see also Livingstone \& Guile, 2012). Employees need so-called $21^{\text {st }}$ century skills such as critical thinking, creativity, collaborative skills and the ability to be innovative (e.g. Griffin \& Care, 2015), and several influential Dutch advisory committees emphasize the need for talent development and management, innovation and differentiation in education (e.g. Commissie Toekomstbestendig Hoger Onderwijs Stelsel, 2010; Wetenschappelijke Raad voor het Regeringsbeleid, 2014). So, under neoliberal conditions too, I plead for liberal pedagogy. On the one hand, liberal pedagogy scaffolds $21^{\text {st }}$ century skills such as critical thinking about ideas, structures, and modes of being, meanwhile fostering creativity (Clegg, 2008). On the other hand, liberal pedagogy creates the opportunity for personal influence, talent development and individual flourishing.

To summarise, it appears clear there is an issue which expresses itself in the field of secondary education. Students within upper secondary education are constrained by a curriculum heavily focused on vocational skills and internships with little space for liberal, critical thinking and teaching, which is demonstrated by limited access to, and study success in, HE. They seem insufficiently prepared for $\mathrm{HE}$ and the changing labour market, of which the latter asks for graduates with skills more often taught in HE than in (upper) secondary education. The crux form cognitive critical and analytical capacities that are needed in both HE and within 'modern' jobs, capacities that are useful for neoliberal purposes but 
commonly fostered and promoted in liberal education. Not only does this complicate educational careers and opportunities, it also adds to inequality in social terms, access to and participation in HE, and employability. Although examples are based on The Netherlands, the issues and concerns are widespread ${ }^{1}$. Similar to The Netherlands (e.g. Van Houten, 2018) debates exist in, for instance, Denmark (e.g. Jørgensen, 2017), Canada (e.g. Wheelahan, 2015), the UK (e.g. Hodgson \& Spours, 2017; Thompson, 2009), and Sweden (e.g. Köpsén, 2019), calling for a reconsideration, to which this paper provides input.

\section{A probable future}

In sections two and three, I aim at what Peters (2003) considers to be foresight planning, namely adding to the discussion to encourage reaching a 'desirable future' among the educational sector groups involved. In this section, I will analyse a probable future, considering three issues. First, autonomy in education is considered. Then the effect of globalisation on the curricula and autonomy is discussed, after which I deal with my concerns regarding the gap between upper secondary education and tertiary (vocational) education.

Autonomy is central to liberal education and has long been an aim of education (Hedge \& Mackenzie, 2016). Adopting White's (2003, p. 147) definition of an autonomous individual being someone 'who determines how he or she should live according to their own, unpressured, picture of a worthwhile life,' I agree with Hedge and MacKenzie (2016) that school education should enable one to become such a person. One of the features of this autonomous life, Hedge and MacKenzie (2016) hold, is that it is largely self-regulated or self-governed, and Dearden (1972) believes that this means that at least important areas of life are determined by oneself. Nussbaum (1997) emphasizes the need for ownership of thought and speech. Hence, for autonomy, choice and freedom of acting are essential.

Following Dearden (1972), there are two kinds of autonomy features that can be distinguished: qualities of the person, such as self-knowledge and morality, and qualities of the mind, such as critical thinking and making assessments. The skills needed in HE as set out earlier, such as critical thinking, can be considered qualities of the mind, and in Dearden's view would be part of autonomy. Bridges (1997), reviewing the body of literature in philosophy in education, questions whether all ingredients said to be part of autonomy should be taught in school, or that they may not necessarily belong to education. However, as Sneyers and De Witte (2016) indicate that particularly intellectual skills, above knowledge, are important for success in HE, it seems fair to expect that at least those ingredients required for $\mathrm{HE}$ are in some form taught in preceding education. Therefore, within the context of the problem discussed in this paper, qualities of the mind might be especially necessary to develop in secondary education as they support 
both autonomy and valued skills. This does not mean I adopt the view that autonomy merely consists of thinking, understanding and the mind. But considering it is these capacities that hinder upper secondary students the most to continue flourishing and developing after graduating in $\mathrm{MBO}$ or succeed in $\mathrm{HE}$, they apparently are of significance in HE.

Although freedom of speech and thought should be a common good in western education, the actual teaching of communication skills and rational thinking as a means to scaffold the capability to use the freedom available is important to support autonomous individuals. Upper secondary education programmes focus, within a taut timeframe, heavily on vocational content and core subjects like arithmetic or mathematics, and language. It is exactly this curriculum, with little choice, that prepares students for $21^{\text {st }}$ century vocation, but also, by extension, for HE. Therefore, it is desirable to spend time on qualities of the mind and develop reasoning, analytical and decision-making skills. In this context, Hedge and MacKenzie (2016, p. 11) maintain that students 'would benefit from an educational environment in which debate, discussion, dissent, speculation, doubt and questioning, about anything and everything, are permitted and encouraged.' Given the current neoliberal focus and curricula, I doubt whether there is sufficient space and time to create the environment Hedge and MacKenzie plead for, yet underline the possible benefits of such an environment.

The focus on core subjects and vocational content knowledge in upper secondary education has undoubtedly been influenced by globalisation. According to Enslin (1999), in education, globalisation has fostered an increasingly common curriculum across countries with an international emphasis on competencies and outcomes. Some of such curricula are based on the concept of competence-based learning and teaching. Significant elements for the development and nature of competence-based learning (as indicated by Tuxworth, 1989) are a demand for greater accountability in education and for increased emphasis on the economical dimension of education, both fitting the neoliberal developments. Meanwhile the EU, in its Lisbon agenda, aims at the EU becoming 'the most competitive and dynamic knowledge-based economy in the world' (European Council, 2000, para. 6) and this also influences countries' education (policy). The Dutch government for instance, acknowledging global connectedness and the importance of knowledge economies, sees it as its responsibility to enable students to flourish in the European knowledge society (OCW, 2000) and in 2015 presented its strategic agenda for higher education until 2025 (OCW, 2015). In the introduction, OCW (2015) mentions globalisation several times as a major driver of educational change and adaption of education to the international (labour) market. Although this agenda concerns $\mathrm{HE}$, the ministry governs both $\mathrm{HBO}$ and $\mathrm{MBO}$ and a significant difference in vision for the two sectors is unexpected. I would like to point out that 'flourishing' in this context relates to being employable or marketable, as opposed to 'liberally flourishing' for a student's own well-being. Neoliberal 
curriculum design prioritizes the market and the whole, picturing the individual within this framework, whereas Enslin (1999) states that in liberalism the individual is prior to society. This development seems to contrast autonomy in terms of freedom to influence one's own curriculum. HEIs are expected to operate neoliberally, being more actively involved in the education of employees and the unemployed in cooperation with trade and industry parties (Sociaal Economische Raad, 1999) - a way of governing common in HEIs over the past two or three decades (e.g. Giroux, 2015; Morrissey, 2015). Globalisation in this sense seems what Heywood (2003) calls 'neoliberal globalism', which according to Mitrovic (2005) relates to further global expansion of economic market-oriented structures, values and concepts.

I expect the middle range future to continue to present a neoliberal educational landscape because of the continuing neoliberal condition within education and global development of the education sector in general. Especially in HE, competitiveness and comparability led to the 'common' curriculum Enslin (1999) mentions. In recent years, upper secondary education followed this discourse in order to compete with other institutions and deliver competitive graduates that will still be valuable and might be able to proceed to HE. The autonomy of the student, and particularly the possibility to influence a curriculum and one's own learning trajectory, will remain limited for some years to come due to the fixedness of the qualification criteria, the obligatory hours for coursework and internships, and the increasing emphasis on arithmetic, languages and competitive market-oriented skills.

The probable future could also bring some liberal features in education. Remarkably, the Dutch strategic agenda for HE until 2025 (OCW, 2015) proposes some interesting goals on liberalisation. However, change often does not happen overnight, and moreover, these proposals and aims concern HE. Another concern arises here. The (proposed) measures and changes for higher education seem to allow for liberal influences, but secondary education appears to adapt slower, at the risk of widening the gap between secondary and tertiary education. With this agenda, the Dutch government aims at 'world-class education' and fulfilling its ambition to offer higher education that enables students to get the most out of themselves, for which it is necessary to pay attention to both qualifications as well as socialisation and development of the self. Liberal 'flourishing' is reflected in such an aim, although the cause still is neoliberal: the ministry (OCW, 2015) writes there are many sufficiently qualified people, but it is just a matter of getting the right person in the right place. The right person and place do not primarily refer to the match between place and personality or self, but to vacancies and labourers. At the same page, the ministry mentions that within branches where shortages exist or might rise, they work towards solutions, implying that students are being prepared for, or shaped to fit, certain positions within the labour market. This strategy resembles individuals as described by Fougner (2006, p. 
176) as entities 'constituted and acted upon as flexible and manipulable subjects' and indeed, as mentioned earlier, defines the individual through market-driven notions the way Giroux (2002) predicts. Nevertheless, this agenda opens up opportunities for choice, for individuals to adapt the course of their education and curriculum and to develop talents and personality. Proper education, OCW (2015) believes, is embedded in groups in which critical discussion and reflection are foundational. One of the spearheads concerns talent development, another diversity. Flexible routes to and through (higher) education should be made possible. After all, the ministry expresses that higher education should offer opportunities to everyone to flourish, develop talents and reach the highest personal level possible. The newest answer to the neoliberal competition, it seems, is diversity and flexibility through liberal-like education by providing choice, critical thinking and self-development, adding personal elements to already well-established programmes and curricula under neoliberal conditions.

This may seem like acceptable for a future, were it not for some concerns that take me back to this paper's central issue of proceeding on the educational ladder. First, the very focus of the agenda, reflected in the subtitle: Strategic Agenda Higher Education and Research 2015-2025. The agenda is focussed on HE and strategic by its very nature, and does not include much about education prior to HE. Yet, it is not just the Dutch government that seems to increasingly attach value to HE. Governments and HEIs themselves have been involved in the marketisation of higher education, which is a growing worldwide trend with market steering replacing or supplementing government steering (Brown \& Carasso, 2013). Partially, this is to widen participation, partially, it is a direct consequence of neoliberal influences (see Molesworth et al., 2010). Recalling Wringe's (1997) liberal view mentioned in the introduction, I question whether the curricular choices offered are to serve one's own aims, or rather are meant to serve the goals, interests and aspirations of others, such as governments or companies.

Fact is that HE students are presented with a broad range of choices. As far as The Netherlands are concerned, this is particularly worrying to me, because the Dutch upper secondary education sector's agenda, called The MBO in 2025 (MBO-Raad, 2015) has a different focus. Cornerstones of that agenda are connection of programmes to the labour market and employment perspectives, the teaching of general skills and courses such as arithmetic and languages, opportunities for lifelong learning, and the construction of examination terms and curricula in cooperation with employers. These values and the upper secondary education skills and curricula explicitly reflect neoliberal education even stronger than those for HE discussed above. The strong neoliberal focus on employers, the market and vocational training in upper secondary education seem to result in a neoliberal focus under neoliberal conditions, contrasting the HE sector becoming increasingly flexible and incorporating liberal elements, even though the conditions remain neoliberal. At the same time, it decreases the space for liberal 
pedagogy skills and alignment with HE using, for instance, continuing learning trajectories. If agendas and standpoints in play differ in focus and content, they might very well emphasize the gap between students and their skills and capacities in secondary and tertiary education, making for a probable but less preferable future.

\section{A preferable future}

The discrepancy between secondary and tertiary vocational education in terms of necessary skills and liberal education elements on the one hand, and the curricula and vocation-related focus on the other, could reinforce the gap between the two levels of education, having an effect on the continuation of $\mathrm{MBO}$ graduates to HE, on their equality matters. In a preferable future, gaps between secondary education and HE would be minimized, and influences of liberal pedagogy in upper secondary education would foster individual development and enable students to develop those capacities needed to actually continue their educational and developmental journey. Apart from the importance of rational and critical thinking skills in HE for practical, vocational purposes, the need for a more liberal approach in upper secondary education also arises from the increased prominence of values, ethics and ideologies in vocational education in general. More than ever before this is a central issue because today's education prepares tomorrow's leaders, leaders that will need values and are capable of critically analysing and debating ethical and content-related matters (OCW, 2015). In the following, I will suggest desirable elements for an educational future that adequately prepares and supports secondary education learners, and argue how this future could contribute to (more equal) opportunities and increased liberal outcomes for students in vocational education.

A more liberal approach in upper secondary education would at least provide students with greater levels of autonomy. This autonomy could present itself in two ways. First, it would offer curricular opportunities operationalised as an undesignated space in the curriculum on the one hand, and courses or activities to be chosen by the student on the other. In HE, institutions already offer minors a package of coherent courses within a certain theme or discipline - allowing for a personal influence on one's curriculum. Minors and cooperation or exchange of students between upper secondary vocational education institutions would increase the range of choice and possibilities for creating one's own curriculum and personal profile. However, the room for self-regulation does not have to be narrowed down to the mere curriculum. The second representation of autonomy would relate to critical thinking, discussion and debate, and ownership of thought and speech as advocated by amongst others Nussbaum (1997) and Hedge and MacKenzie (2016). If ownership of the learning process is considered important, students should also be able to influence everyday teaching and 
learning in order to govern their individual process. Problem Based Learning (PBL) for example, making use of situations encountered at work or privately, increases a student's impact on the learning process in general (Duncan \& AlNakeeb, 2006) and creates ownership (Cockrell et al., 2000). Duncan and Al-Nakeeb (2006) and Duncan et al. (2007) show advantages when making use of such learning strategies: students perceive to improve critical thinking skills and autonomy. This suggests that more autonomy in education not only means creating opportunities to choose programmes or courses, but also offering opportunities to self-direct learning in order to scaffold the learning of critical thinking within these programmes and courses. It seems Dearden's (1972) qualities of the mind would receive greater attention with more autonomous students providing input to their learning process. PBL or other types of non-traditional learning that allow for students to create their learning environment relate to both choice and the possibility to use one's life to serve one's own goals, as liberal education prescribes. Moreover, it recognizes the importance of acquiring knowledge through enquiry, fostering analysis. Furthermore, individual influence and freedom of speech might create a context in which personalities and diversity become visible, that way contributing to a joint level playing field for secondary and tertiary vocational education graduates.

Secondary education, as foundational education, is supposed to create opportunities to proceed to and succeed in HE. To a certain extent, legally these chances to continue on a higher education level depend on the level of the diploma obtained. An assumption behind this is that once an individual has obtained a diploma at a certain level, they are prepared for the next step. The discussion in section one calls the validity of this assumption into question. Partially, these chances to succeed also bank on the actual capacities and skills of students. The statistics and arguments suggest a discrepancy between the chances and actual continuation to HE. These findings provide grounds to argue for a future that deals with the discrepancy, or gap, between attained skills and necessary skills and to smoothen the transfer from secondary education to HE, preferably by balancing examination requirements in secondary education with entry requirements and expectations in HE.

In order to increase the level of critical thinking, rational and analytical skills, these skills should be taught previous to HE. In pursuance of this, the actual teaching and scaffolding of skills that are valued in HE should be incorporated in the curricula and/or in the teaching methods of programmes that grand access to HE. Terenzini et al. (1995) indicate that the more time students have to study, the more gains in critical thinking may be expected. This emphasizes the importance of starting early and providing time to grow. Building on a greater critical thinking capacity, continuing secondary education graduates would also benefit later on in their careers as well - according to Donald (1985) this critical thinking capacity is needed for other skills such as disciplined inquiry and 
analysis. Liberal influences in (upper) secondary education therefore should not be limited to allowing greater autonomy, but also by reserving a part of the actual educating for liberal pedagogical aims of education, in particular critical thinking and reasoning.

The discrepancy mentioned earlier suggests a lack of coordination concerning continuity and the learning process of 'liberal skills'. Absence of continuing learning-teaching trajectories and the struggle HEIs' teachers experience with 'transferred' or continuing students, Herweijer and Turkenburg (2016) point out, implicate a lack of coordination and cooperation. To encourage reaching a consensus concerning a 'desirable future' among different education sectors, some kind of cooperation between them is desirable, if not necessary. The Dutch MBO sector's council for instance pleads for continuing learning trajectories (Berkhout, 2019), and the Dutch Ministry and some HBO institutions such as the Hogeschool van Amsterdam (Amsterdam University of Applied Sciences) express the ambition for the sector to actively create collaborative relationships with upper secondary education (Hogeschool van Amsterdam, 2015; OCW, 2015). The purpose of this collaboration, however, should not only be to familiarize upper secondary education students with the lay of the higher education land, but also to actually scaffold and teach skills that would benefit these students anyhow. It may be the case that preparing students for HE primarily is a task for upper secondary education institutions, but alignment and cooperation can smoothen the execution of this task. Minors-like programmes in upper secondary education, as mentioned earlier, could serve as a vehicle for bridging trajectories between upper secondary curricula and the first year in HE. Herweijer and Turkenburg (2016) indicate that in The Netherlands, the HE sector expects that the recently introduced minors in $\mathrm{MBO}$ will indeed act as transition vehicles. To make this happen, such minors' content should not only cover cognitive requirements but also other (study) skills. In order to be pragmatic, communication and collaboration between the sectors and institutions is essential. If the HE sector expects better prepared students, and upper secondary schools are expected to deliver these, those educators designing and teaching the minors have to maintain collaborative relationships with both upper secondary and HE vocational representatives.

\section{Concluding thoughts}

The neoliberal, global context seems to have contributed to pragmatic, hands on curricula in upper secondary education with little space for personality and criticism. Giroux (2002) concisely sketches this context when writing that if society is defined through the culture and values of neoliberalism, critical education as condition for creating thoughtful and engaged citizens is sacrificed to the interest of financial capital and the logic of profit-making. Taking the Dutch context as example, the preparatory education, legal routes to $\mathrm{HE}$, and the EQF level $6 \mathrm{HBO}$ 
bachelor's degree curricula cause a delicate situation for upper secondary education students. Preferably, liberal pedagogy and $21^{\text {st }}$ century skills are fostered in upper secondary education, but teaching marketable skills overshadows liberal pedagogy. Although in The Netherlands minors have been introduced in upper secondary education, it is not entirely clear which deficiencies are targeted, and judging by the content of the minors developed so far, it seems to me the focus lies on content and practical skills, not so much (yet) on cognitive, analytical capacities. This signals the need to carefully (re)consider the content of curricula and bridging programmes. Furthermore, apart from their preparedness, the success rate of upper secondary education graduates in $\mathrm{HE}$ also derives from a students' choice of HE programme. Being provided with information about study options and learning about one's interests and talents within curricula prior to HE contributes to making a better, more adequate choice, although there is no guarantee the right choice will be made (Warps, 2013). If the aim is, to use Giroux's words, to educate 'thoughtful and engaged citizens' (2002, p. 427) that are able to be responsible and critical employees, with attention for talent and differentiation as governments propose, then liberal pedagogy should be embedded in education from an earlier age and at least in programmes preparing for HE. In the longer term, liberal pedagogy and critical thinking could very well scaffold the development of both talented and creative personalities (Clegg, 2008) as well as a competitive, critical, analytical workforce. After all, neoliberalism primarily is a tendency and condition, leaving room for a pedagogy supporting individual and societal development.

\section{Endnote}

${ }^{1}$ For more on this topic: Blossfeld, H., Buchholz, S., Skopek, J., \& Triventi, M. (Eds.) (2016). Models of secondary education and social inequality. Cheltenham, UK: Edward Elgar Publishing.

\section{Acknowledgements}

I am grateful to Björn Eussen, Christina Burke and Jan Simon Brouwer for providing me with critical feedback on this paper's drafts, and to Nicki Hedge and Penny Enslin, for scaffolding my understanding and writing.

\section{Disclosure statement}

This is to acknowledge that no financial interest or benefit that has arisen from the direct applications of my research. 
Individual development in a neoliberal context: Climbing to a 'glass ceiling'?

\section{Note on contributor}

Maarten van Houten is affiliated with the University of Glasgow, where he is a doctoral candidate focussing on knowledge sharing between teachers in vocational education and learning organisations. He has taught within secondary education, has worked as both a teacher and a (programme and curriculum) coordinator within upper secondary vocational education in Amsterdam, and has experience as a lecturer and teacher trainer at the Amsterdam University of Applied Sciences. 


\section{References}

Asselt, R. van (2014). Analyse en mogelijke verklaringen van de dalingen van de studiesuccessen van mbo'ers en havo'ers na 5 jaar voltijd hbo-studie van de uitstroom in 2008 tot en met de uitstroom 2012 [Analysis and possible explanations of the decreases in the study successes of MBO students and HAVO students after 5 years of full-time HBO study of the outflow in 2008 up to and including the outflow 2012]. Retrieved 22. January, 2020, from https://nvvw.nl/wp-content/uploads/2017/02/Analyse-doorstroomrendement-HBO-eindversie.pdf

Billing, D. (2007). Teaching for transfer of core/key skills in higher education: Cognitive skills. Higher Education, 53(4), 483-516.

Bridges, D. (1997). Personal autonomy and practical competence. Developing politically effective citizens. In D. Bridges (Ed.), Education, Autonomy and Democratic Citizenship (pp. 153-164). London, UK: Routledge.

Berkhout, M. (2019). Doorstroom mbo-hbo [Continuation mbo-hbo]. MBO-raad. Retrieved 22. January, 2020, from https://www.mboraad.nl/themas/doorstroom-mbo-hbo

Bussemaker, J. (2013, December 5). Doorstroom MBO-HBO [Continuation MBOHBO][Letter to parliament, ref. 547492].

Brown, R., \& Carasso, H. (2013). Everything for sale? The marketisation of UK higher education. London, UK: Routledge.

CEDEFOP. (2011). Labour-market polarisation and elementary occupations in Europe: Blip or long-term trend? Cedefop Research paper 5509. Thessaloniki: Cedefop. Retrieved 22. January, 2020, from

https://www.cedefop.europa.eu/files/5509_en.pdf

Clegg, P. (2008). Creativity and critical thinking in the globalised university. Innovations in Education and Teaching International, 45(3), 219-226.

Cockrell, K.S., Caplow, J.A., \& Donaldson, J.F. (2000). A Context for Learning: collaborative groups in the problem-based learning environment. The Review of Higher Education, 23(3), 347-363.

Commissie Toekomstbestendig Hoger Onderwijs Stelsel. (2010). Differentiëren in drievoud omwille van kwaliteit en verscheidenheid in het hoger onderwijs [Differentiate in triplicate for quality and diversity in higher education]. Retrieved 22. January, 2020, from https://research.utwente.nl/en/publications/differenti\%C3\%ABren-in-drievoud-omwille-van-kwaliteit-en-verscheidenhe

Dearden, R.F. (1972). Autonomy and education. In R.F. Dearden, P.H. Hirst \& R.S. Peters (Eds.), International library of the philosophy of education, Vol. 8. Education and the development of reason (pp. 448-465). London, UK: Routledge \& Kegan Paul.

Donald, J.G. (1985). Intellectual skills in higher education. The Canadian Journal of Higher Education, 15(1), 53-68. 
Individual development in a neoliberal context: Climbing to a 'glass ceiling'?

Duncan, M.J., \& Al-Nakeeb, Y. (2006). Using Problem Based Learning in Sports Related Courses: an overview of module development and student responsesin an undergraduate sports studies module. Journal of Hospitality, Leisure, Sport and Tourism Education, 5(1), 50-57.

Duncan, M., Lyons, M., \& Al-Nakeeb, Y. (2007). 'You have to do it rather than being in a class and just listening.' The impact of problem-based learning on the student experience in sports and exercise biomechanics. Journal of Hospitality, Leisure, Sport and Tourism Education, 6(1), 71-80.

Enslin, P. (1999). Education for liberal democracy: Universalising a western construct? Journal of Philosophy of Education, 33(2), 175-186.

European Council. (2000, March 23-24). Presidency conclusions. Lisbon European Council. Retrieved 22. January, 2020, from http://www.europarl.europa.eu/summits/lis1_en.htm

Fougner, T. (2006). The state, international competitiveness and neoliberal globalisation: is there a future beyond 'the competition state'? Review of International Studies, 32(1), 165-185.

Giroux, H. (2002). Neoliberalism, corporate culture, and the promise of higher education: The university as a democratic public sphere. Harvard Educational Review, 72(4), 425-463.

Giroux, H.A. (2015). Public intellectuals against the neoliberal university. In K. Denzin, \& M.D. Giardina (Eds.), Qualitative inquiry - past, present, and future: A critical reader (pp. 194-221). New York: Routledge.

Goos, M., Manning, A., \& Salomons, A. (2010). Explaining job polarization in Europe: The roles of globalization, technology and institutions. Centre for Economic Performance. Retrieved 22. January, 2020, from http://cep.lse.ac.uk/pubs/download/dp1026.pdf

Griffin, P., \& Care, E. (Eds.) (2015). Assessment and teaching of 21st century skills. The Netherlands: Springer.

Heywood, A. (2003). Political ideologies: An introduction (3 $3^{\text {rd }}$ ed.). London, UK: Palgrave Macmillan.

Hedge, N., \& MacKenzie, A. (2016). Scotland's curriculum for excellence: A defence of autonomy and personhood. Oxford Review of Education, 42(1), 1-15.

Herweijer, L., \& Turkenburg, M. (2016). Wikken en wegen in het hoger onderwijs [Hemming and hawing in higher education]. Sociaal en Cultureel Planbureau. Retrieved 22. January, 2020, from https://www.scp.nl/dsresource?objectid=6a6e95fd-aba1-44b9-877a-899ba791bba7\&type=org

Hodgson, A., \& Spours, K. (2017, September). FE and skills across the UK: The case of England [Seminar briefing paper]. FE and Skills across the UK seminar, London, England.

Hogeschool van Amsterdam. (2015). Jaarverslag 2015 [Annual report 2015]. Retrieved 22. January, 2020, from http://www.hva.nl/binaries/content/assets/hva/over-dehva/hva-jaarverslag-2015-def.pdf?1467288334187 
Houten, M.M. van (2018). Vocational education and the binary higher education system in the Netherlands: Higher education symbiosis or vocational education dichotomy? Journal of Vocational Education E Training, 70(1), 130-147.

Inspectie van het onderwijs. (2015). Selectie en toegankelijkheid van het hoger onderwijs. Deelrapport a: Verkenning naar maatregelen rond in- en doorstroom in het bacheloronderwijs [Selection and accessibility of higher education. Sub-report a: Exploration of measures related to entry and transfer in bachelor's education]. Retrieved 22. January, 2020, from https://www.onderwijsinspectie.nl/binaries/onderwijsinspectie/documenten/rapporten/2015/12/15/onderzoekselectie-en-toegankelijkheid-hoger-onderwijs/Rapport+Selectie+toegankelijkheid+hoger+onderwijs+In+en+doorstroom+bacheloronderwijs+deelrapport+a.pdf

Jørgensen, C.H. (2017). From apprenticeships to higher vocational education in Denmark: Building bridges while the gap is widening. Journal of Vocational Education \& Training, 69(1), 64-80.

Köpsén, J. (2019). Demands-based and employer-driven curricula: Defining knowledge in higher vocational education and training. Studies in Continuing Education. Advance online publication.

Livingstone, D.W., \& Guile, D. (Eds.) (2012). The knowledge economy and education, vol. 4: The knowledge economy and lifelong learning. A critical reader. Rotterdam: Sense Publishers.

Lowe, H., \& Cook, A. (2003). Mind the gap: Are students prepared for higher education? Journal of Further and Higher Education, 27(1), 53-76.

Magretta, J. (2002). Why business models matter. Harvard Business Review, 80(5), 86-92. Retrieved 22. January, 2020, from https://hbr.org/2002/05/why-business-models-matter

MBO-Raad. (2015). Het mbo in 2025: Manifest voor de toekomst van het middelbaar beroepsonderwijs [The MBO in 2025: Manifest for the future of upper secondary education]. Retrieved 22. January, 2020, from

https:// www.mboraad.nl/sites/default/files/publications/het_mbo_in_2025_manifest_voor_de_toekomst_van_het_mbo.pdf

MBO-Raad. (2019). Studenten in het MBO [Students in MBO]. Retrieved 22. January, 2020, from https://www.mboraad.nl/het-mbo/feiten-en-cijfers/studenten-het-mbo

Ministerie van Onderwijs, Cultuur \& Wetenschap. (2000). Naar een open hoger Onderwijs [Towards an open higher education] [Policy brief].

Ministerie van Onderwijs, Cultuur \& Wetenschap. (2015). De waarde(n)van weten: Strategische agenda hoger onderwijs en onderzoek 2015-2025 [The value(s) of knowing: Strategic agenda higher education and research 2015-2025]. Retrieved 22. January, 2020, from https://www.rijksoverheid.nl/binaries/rijksoverheid/documenten/beleidsnota-s/2015/07/07/de-waarde-n-van-weten- 
Individual development in a neoliberal context: Climbing to a 'glass ceiling'?

strategische-agenda-hoger-onderwijs-en-onderzoek-2015-2025/strategischeagenda-hoger-onderwijs.pdf

Mitrovic, L. (2005). Bourdieu's criticism of the neoliberal philosophy of development, the myth of mondialization and the new Europe. (An appeal for the renewal of critical sociology). Philosophy, Sociology and Psychology, 4(1), 37-49.

Molesworth, M., Scullion, R., \& Nixon, E. (Eds.) (2010). The marketisation of higher education. London, UK: Routledge.

Morrissey, J. (2015). Regimes of performance: Practices of the normalised self in the neoliberal university. British Journal of Sociology of Education, 36(4), 614-634.

Naglieri, J.A. (2005). The cognitive assessment system. In D. Flanagan, \& P. Harrison (Eds.), Contemporary intellectual assessment: Theories, tests and issues (pp. 441-460). New York: Guilford Press.

Naglieri, J.A., \& Das, J.P. (2005). Planning, attention, simultaneous, successive (PASS) theory: A revision of the concept of intelligence. In D. Flanagan, \& P. Harrison (Eds.), Contemporary intellectual assessment: Theories, tests and issues (pp. 120-135). New York: Guilford Press.

Nussbaum, M.C. (1997). Cultivating humanity; A classical defense of reform in liberal education. Cambridge, MA: Harvard University Press.

Onderwijsincijfers. (n.d.a.). Studiesucces in het hoger beroepsonderwijs [Study success in higher education]. Retrieved 22. January, 2020, from https://www.onderwijsincijfers.nl/kengetallen/hbo/studenten$\underline{\mathrm{hbo} / \text { prestaties-studiesucces-in-het-hbo } \backslash \backslash}$

Onderwijsincijfers. (n.d.b.). Doorstroom van het mbo naar het hbo: Doorstroomkansen en studiesucces over de tijd [Continuation from mbo to hbo: Opportunities for continuation and study success over time]. Retrieved 22. January, 2020, https://www.onderwijsincijfers.nl/themas/transities-in-het-onderwijs/doorstroom-van-mbo-naar-hbo

Peters, M. (2003). Educational policy futures. Journal of Futures Studies, 8(1), 3952.

Sneyers, E., \& Witte, K. de (2016). Doorstroom MBO-HBO en uitval in het HBO: Evidence-based aanbevelingen [Continuation $\mathrm{MBO}-\mathrm{HBO}$ and drop-outs in $\mathrm{HBO}$ ]. Retrieved 22. January, 2020, from http://www.tierweb.nl/tier/assets/files/UM/projects/doorstroom $\% 20 \mathrm{mbo} \% 20 \mathrm{hbo} /$ Literatuuronderzoek\%209-6.pdf

Sociaal en Cultureel Planbureau. (2004). In het zicht van de toekomst: Sociaal en cultureel rapport 2004 [The future in sight: Social and cultural report 2004]. Sociaal en Cultureel Planbureau. Retrieved 22. January, 2020, from https:/ / www.scp.nl/dsresource?objectid=9cbd870b-ad0e-49e0-a29e14b8ce8671ab\&type $=$ org

Sociaal Economische Raad. (1999). Hoger onderwijs en onderzoek plan 2000 [Higher education and research plan 2000] (Advice nr. 99/04). Retrieved 22. January, 
2020, from https://www.ser.nl/-/media/ser/downloads/adviezen/1999/hoger-onderwijs-onderzoek-plan.pdf

Terenzini, P.T., Springer, L., Pascarella, E.T., \& Nora, A. (1995). Influences affecting the development of students' critical thinking skills. Research in Higher Education, 36(1), 23-39.

Thompson, R. (2009). Creativity, knowledge and curriculum in further education: A Bernsteinian perspective. British Journal of Educational Studies, 57(1), 37-54.

Tuxworth, E. (1989). Competence based education and training: Background and origins. In J. Burke (Ed.), Competency-based education and training (pp. 9-22). London: Routledge.

Warps, J. (2013). Lob en studiesucces: Onderzoek naar de opbrengst van LOB op basis van de Startmonitor 2012-2013 [LOB and study success: Study on the revenues of LOB based on the Startmonitor 2012-2013]. WUR. Retrieved 22. January, 2020, from https://www.wur.nl/web/file?uuid=3c14154b-e8f4-4bd3-9d9d10ca34be835c\&owner=83ad3cb9-21f2-4099-86bc-f3dba6191ad0

Weert, C. van, Meijer, R., Bakker, K., \& Tan, S. (2017). Toegankelijkheid van het hoger onderwijs voor mbo 4-gediplomeerden: De rol van inkomen en andere achtergrondkenmerken [Accessibility of higher education for mbo 4 graduates: The role of earnings and other background characteristics] (Report no. 3.3.4). Centraal Bureau voor de Statistiek. Retrieved 22. January, 2020, from https://www.cbs.nl/Lmedia/_pdf/2017/37/170914toegankelijkheidhovoormboers_rapport.pdf

Wetenschappelijke Raad voor het Regeringsbeleid. (2014). Naar een lerende Economie: Investeren in het verdienvermogen van Nederland [Towards a learning economy: Investing in the earning capacity of The Netherlands] (Report no. 90). Retrieved 22. January, 2020, from https://www.wrr.nl/binaries/wrr/documenten/rapporten/2013/11/04/naar-een-lerende-economie/R090-Naar-lerende-economie.pdf

Wheelahan, L. (2015). Not just skills: What a focus on knowledge means for vocational education. Journal of Curriculum Studies, 47(6), 750-762.

White, J. (2003). Five critical stances towards liberal philosophy of education: With Responses from Wilfred Carr, Richard Smith, Paul Standish \& Terence H. McLaughlin. Journal of Philosophy of Education, 37(1), 147-184.

Wringe, C. (1997). In defence of rational autonomy as an educational goal. In D. Bridges (Ed.), Education, autonomy and democratic citizenship (pp. 115-126). London, UK: Routledge. 